\title{
PECULIARITIES OF THE HIGHER EDUCATION DEVELOPMENT IN A BLENDED LEARNING ENVIRONMENT
}

\author{
PECULIARIDADES DO DESENVOLVIMENTO DO ENSINO SUPERIOR EM UM \\ AMBIENTE DE APRENDIZAGEM HÍBRIDA
}

\author{
PECULIARIDADES DEL DESARROLLO DE LA ENSEÑANZA SUPERIOR EN UN \\ ENTORNO DE APRENDIZAJE MIXTO
}

\author{
Pavlo CHERVONYI ${ }^{1}$ \\ Svitlana ALIEKSIEIEVA ${ }^{2}$ \\ Nadiia SENCHYLO-TATLILIOGLU ${ }^{3}$ \\ Oleksandr CHASTNYK ${ }^{4}$ \\ Nataliia DIOMIDOVA ${ }^{5}$
}

\begin{abstract}
This article aims to identify the peculiarities of the higher education pedagogy transformation through the blended learning model. The methodology was based on a statistical, correlational analysis by using The Teaching and Learning International Survey database containing the survey results of 7,823 educators in France and the Netherlands. The study revealed an average level of teacher preparation for blended learning $(50.5 \%)$ and preparation for the inclusion of components of information and communication technology (ICT) use in student learning (48.4\%). A significant level of teachers' professional development of ICT skills was revealed (44\% take courses). An average level of teachers' unpreparedness both for blended learning (28.9\% not ready, $36.6 \%$ not prepared enough) and ICT use in practice was established (30.3\% almost not ready, 34.25 not prepared enough). A positive correlation was established between the teachers' preparation for the blended learning environment and the passage of professional ICT skills development courses.
\end{abstract}

KEYWORDS: Pedagogy. Blended learning. Environment.

RESUMO: Este artigo identifica peculiaridades da transformação da pedagogia do ensino superior através do modelo de aprendizagem combinada. A metodologia baseou-se numa análise estatística e correlacional, utilizando a base de dados do The Teaching and Learning

\footnotetext{
${ }^{1}$ Kharkiv National University of Internal Affairs (KHNUIA), Kharkiv - Ukraine. Docent of pedagogic and psychology, Department of Pedagogy and Psychology. Candidate of pedagogical Sciences. ORCID: https://orcid.org/0000-0002-8172-7732. E-mail: nepavel@ukr.net

${ }^{2}$ Institute of Pedagogy of the National Academy of Pedagogical Sciences of Ukraine (IPNAPNU), Kyiv Ukraine. Doctor of pedagogical Sciences, Senior research. ORCID: https://orcid.org/0000-0002-8132-0465. Email:sv-05@ukr.net

${ }^{3}$ National Aviation University (NAU), Kyiv - Ukraine. PhD in Philology, Associate Professor, Department of Ukrainian Language and Culture. ORCID: https://orcid.org/0000-0001-9196-7118. E-mail: ifyc23@gmail.com

${ }^{4}$ Yaroslav Mudryi National Law University (YMNLU) Kharkiv - Ukraine. Candidate of Art Criticism, Department of Foreign Languages. ORCID: https://orcid.org/0000-0001-5188-5097. E-mail: chastnyk@gmail.com

${ }^{5}$ H.S. Skovoroda Kharkiv National Pedagogical University (SKhNPU), Kharkiv - Ukraine. Associate Professor, Department of Psychological and Pedagogical Anthropology. PhD in Psychology. ORCID: https://orcid.org/0000-0002-2488-0220. E-mail: nataliia.diomidova@gmail.com
} 
International Survey, contendo os resultados de pesquisa com 7.823 educadores na França e nos Países Baixos. O estudo revelou nível médio de preparação dos professores para a aprendizagem híbrida (50,5\%) e para a utilização das tecnologias da informação e comunicação (TIC) na aprendizagem dos estudantes $(48,4 \%)$. Revelou-se um nivel significativo de desenvolvimento profissional em competências das TIC (44\% fazem cursos) e estabeleceu-se um nível médio de despreparo tanto para aprendizagem híbrida (28,9\% não preparados, 36,6\% insuficientemente preparados) como para utilização das TIC na prática (30,3\% quase não preparados, 34,25 insuficientemente preparados). Estabeleceu-se correlação positiva entre a preparação dos professores para o ambiente de aprendizagem híbrida e a passagem de cursos profissionais de desenvolvimento em TIC.

PALAVRAS-CHAVE: Pedagogia. Aprendizagem hibrida. Ambiente.

RESUMEN: Este artículo pretende identificar las peculiaridades de la transformación de la pedagogía de la enseñanza superior a través del modelo de aprendizaje mixto. La metodología se basó en un análisis estadístico y correlacional utilizando la base de datos de la Encuesta Internacional de Enseñanza y Aprendizaje, que contiene los resultados de la encuesta realizada a 7.823 educadores de Francia y los Países Bajos. Resultados. El estudio reveló un nivel medio de preparación de los profesores para el aprendizaje mixto (50,5\%) y de preparación para el uso de las TIC en el aprendizaje de los alumnos $(48,4 \%)$ componentes de inclusión. Se reveló un nivel significativo de desarrollo profesional de los profesores en cuanto a las competencias en TIC (el 44\% realiza cursos). Se estableció un nivel medio de falta de preparación de los profesores tanto para el aprendizaje combinado (28,9\% no está preparado, 36,6\% no está suficientemente preparado) como para el uso de las TIC en la práctica (30,3\% - casi no está preparado, 34,25 - no está suficientemente preparado). Se estableció una correlación positiva entre la preparación de los profesores para el entorno de aprendizaje combinado y el paso de los cursos de desarrollo de habilidades profesionales en TIC.

PALABRAS CLAVE: Pedagogía. Aprendizaje combinado. Entorno.

\section{Introduction}

Since the early 2000s, the potential of blended learning has been recognized worldwide as a promising trend due to the active development of technology and its integration into higher education (GRAHAM, 2009). The use of various blended learning models is becoming an increasingly common practice in higher education, which experts estimate will become the new traditional model (GRAHAM, 2013b). Consequently, sixteen years of data collected by Moskal, Dziuban and Hartman (2013) show that with proper support, implementation, and planning, blended learning can provide a positive institutional transformation of higher education. The field of higher education has also seen growing trends in the adoption of blended learning, with the development of models, concepts, approaches, and theories guided by researchers advancing at a much slower pace (GRAHAM,

RPGE- Revista on line de Política e Gestão Educacional, Araraquara, v. 25, n. 3, p. 2241-2257, Sep./Dec. 2021. e-ISSN: 1519-9029 DOI: https://doi.org/10.22633/rpge.v25i3.15959 
2013a). Blended learning in higher education is in its developmental stage, which explains the relevance of research on the issues of higher education transformation through the introduction of technology in pedagogy.

This article aims to identify the features of the pedagogy transformation of higher education based on the model of blended learning.

To achieve this aim, the following tasks are set: to determine the essence, advantages, problems of the blended learning form for students, teachers, higher education administration, blended learning model to identify the limitations of empirical research on this issue; and to conduct an empirical study of higher education pedagogy based on the blended learning model.

\section{Literature review}

Defining blended learning as a combination of face-to-face (traditional teaching) and learning through technology formats emphasizes the ongoing convergence of two archetypal learning environments: traditional face-to-face with distributed (or technology-mediated) environments (GRAHAM, 2009). Blended learning is also used to describe combinations such as the combination of different learning methods, pedagogical approaches, and technologies (HRASTINSKI, 2019; SMITH; HILL, 2019).

Vaughan (2007) explored the benefits and challenges of a blended learning form in higher education from the perspectives of students, faculty, and administration. Students argued for time flexibility and improved learning outcomes while at the same time having problems managing their own time, greater responsibility for their learning, and problems using complex and different technologies (VAUGHAN, 2007). A study by López-Pérez, Pérez-Lopez and Rodríguez-Ariza (2011) shows that the use of blended learning positively affects dropout rates, improved exam grades, students' perception of blended learning closely related to final grades. Students' grades are influenced by blended learning activities as well as students' age, background, and course attendance levels.

Teachers make assumptions about opportunities through blended courses to enhance student-faculty interaction, the potential for student engagement in learning, increased flexibility in the teaching environment, and the potential for improvement. Teachers noted that the major challenges of blended learning are the problems of course development, lack of time, resources, and support in course development, the need to learn new teaching skills, and the use of technology (VAUGHAN, 2007). As a consequence, Pulham and Graham (2018) 
argue that the skills needed to teach in online and blended environments are different from those needed for traditional teaching but teacher preparation programs often do not include training courses to learn new ways of teaching. Teacher competencies should address (1) pedagogy, (2) management, (3) assessment, (4) technology, (5) teaching design, (6) disposition, and (7) improvement. Some of the most needed skills for blended teaching include flexibility and personalization, mastery-based learning, using and interpreting data, facilitating online discussions, using a learning management system, and managing the software.

From an administrative perspective, the blended learning form is an opportunity to enhance the reputation of the higher education institution, increase access to the institution's educational offerings, and reduce operating costs. The challenges of this learning form are the need to align this format with institutional goals and priorities, the resistance to organizational change, and the lack of organizational structure, collaboration, and partnership experiences (VAUGHAN, 2007). Graham (2013a) argues for institutional implementation challenges (change and acceptance, access to learning, cost-effectiveness), student challenges (learning effectiveness, engagement, satisfaction), and faculty challenges (satisfaction and workload, professional development).

Looking at the effectiveness of blended learning, Dziuban et al. (2018) argue that the formats of this type of learning are unified by accessibility, academic performance, and student perceptions of the learning environment. The results of Manwaring et al. (2017) showed that course design variables and student perceptions had a greater impact on student engagement during blended learning than individual student characteristics. Students' multitasking had a strong negative effect on involvement. Perceptions of the activity's importance had a strong positive influence on cognitive and emotional involvement. An important outcome of involvement was students' perceptions of their improvement through learning (MANWARING et al., 2017).

Porter et al. (2016) proposed a framework for institutional implementation of blended learning by identifying three steps: (a) awareness/research, (b) adoption/early implementation, and (c) mature implementation/growth.

Graham (2009) conducted a review of blended learning models that began to develop in formal higher education institutions from the early 2000s and gained popularity during 2000-2010. Blended learning models typically focus on the surface, physical characteristics rather than pedagogical or psychological characteristics (PORTER et al., 2014). Hrastinski (2019) discusses different definitions of the blended learning term, models, and 
conceptualizes blended learning and its implications. In particular, Hrastinski's (2019) research allows us to systematize the following models:

- the community of inquiry framework, based on the following types of presence: cognitive, learning, and social presence, in which the community of inquiry is the basis of learning;

- rotation model, which provides for the alternation of different teaching methods, among which are online methods, group or individual projects, and full-class teaching;

- a flexible model that provides for the transfer of content and knowledge through an online environment on students' individualized schedules;

- $\quad$ self-mixing model, where students take one or multiple courses as a supplement to traditional courses;

- an extended virtual model, where students are given the opportunity of allocating time to attend courses and distance learning online.

The results of Porter et al. (2014) on features, trends, models, concepts, and approaches to blended learning reveal a lack of theoretical cohesion among scholars and a need for further research in this area. For example, Graham et al. (2019) noted that there had been little empirical research on preparing educators for blended learning, including the skills they must develop to teach in a blended environment. Graham et al. (2019) presented a measurement model for assessing teacher readiness for blended learning that includes assessment of the following top-level domains: (a) basic knowledge, skills, and dispositions, (b) teaching planning, (c) teaching methods and strategies, (d) assessment (e) management. Pulham, Graham and Short (2018) also point to the need to prepare educators for learning through further research on the skills needed for online and blended learning. Jiuban et al. (2018) conclude that the evolution of blended learning will be inextricably linked to modern information and communication technologies that approximate aspects of human thinking. It means that teachers need to constantly develop digital skills to work effectively in a blended learning environment.

Thus, the scientific literature explores and debates the essence, approaches, models, the concept of blended learning, advantages, and problems for students, teachers, administration of the form of blended learning. There are no comprehensive empirical studies at the national level on the specifics of teachers' preparation for teaching in a blended learning environment and the level of their preparedness, teachers' use of information and 
communication technology (ICT) in learning activities, the effects of professional development of teachers' ICT skills and the need to develop teachers' ICT skills.

\section{Methodology}

This study used secondary data from 2018 The Teaching and Learning International Survey for France and the Netherlands (Table 1). The survey involved an assessment by higher education teachers of the inclusion in training programs of courses on the use of ICT in student learning; the level of readiness to use the skills obtained in such courses in practice; the practice of using information technology; the inclusion in professional development programs of subjects to improve ICT skills for teaching (ORGANISATION FOR ECONOMIC COOPERATION AND DEVELOPMENT, 2019).

In the context of the study to analyze the readiness of teachers for blended learning, were selected issues related to the practice of information technology in the following areas:

1) the inclusion of ICT skills development and ICT use subjects in higher education teacher education programs;

2) the inclusion of technology use subjects in formal teacher education and the practice of teaching these subjects to higher education students;

3) the inclusion of ICT use subjects in teacher professional development programs;

4) the positive impact of training on their use of ICT in practice;

5) the need for further training in ICT use by teachers. 
Table 1 - The questionnaire and survey of teachers on the use of ICTs in elementary school

\begin{tabular}{|l|l|}
\hline Question & Options for answers \\
\hline & (A) Inclusion in formal education: \\
1. Were the following elements included in your formal & 1. Yes \\
education, and to what extent did you feel prepared for & 2. No \\
each element in your teaching? Please mark one choice in & (B) Preparedness: \\
both part (A) and part (B) in each row. & 1. Not at all \\
e) Teaching in a mixed ability setting; & 2. Somewhat \\
h) Use of ICT for teaching. & 3. Well \\
& 4. Very well \\
\hline
\end{tabular}

2. Were the following subject categories included in your formal education, and do you teach them during the current high school year to any students in this school? Please mark as many choices as appropriate in each row. g) Technology Includes orientation in technology, including information technology, computer studies, construction/surveying, electronics, graphics and design, keyboard skills, word processing, workshop technology/design technology.

3. Were any of the topics listed below included in your professional development activities during the last 12 1. Yes months? Please mark one choice in each row. (e) ICT skills for teaching)

\section{Included in my formal education.}

2. I teach it to pupils this year.

2. No

4. Thinking of the professional development activity that had the greatest positive impact on your teaching during the last 12 months, did it have any of the following characteristics? Please mark one choice in each row. (1 Yes, $2-$ No).

a) It built on my prior knowledge.
b) It adapted to my personal development needs.
c) It had a coherent structure.
d) It appropriately focused on content needed to
teach my subjects.
e) It provided opportunities for active learning.
f) It provided opportunities for collaborative
learning.
g) It provided opportunities to practice/apply new
ideas and knowledge in my own classroom.
h) It provided follow-up activities.
i) It took place at my school.
j) It involved most colleagues from my school.
k) It took place over an extended period of time
(e.g., several weeks or longer).
1) It focused on innovation in my teaching.




\begin{tabular}{|l|l}
\hline 5. For each of the areas listed below, please indicate the & 1 - No need at present. \\
extent to which you currently need professional & 2 - Low level of need. \\
development. Please mark one choice in each row. (e) ICT & 3 - Moderate level of need. \\
skills for teaching & 4 - High level of need.
\end{tabular}

Source: Organisation for Economic Cooperation and Development (2019)

Pearson correlation at $1 \%$ significance level was used to identify the link between the variables, in particular, to assess whether teacher training programs affect teachers' readiness for blended learning and the use of ICT in professional activities.

\section{Sampling}

A total of 7,823 French $(56.7 \%)$ and Dutch $(43.3 \%)$ higher education teachers participated in the study, of which $70.1 \%$ were female, and $29.9 \%$ were male (Table 2); $94.93 \%$ of the teachers had a university degree, which increases the likelihood of including ICT skills in teachers' training programs.

In addition, $17 \%$ of teachers have $0-5$ years of higher education work experience, $17 \%$ have 6 - 10 years of work experience, $18 \%$ have 11 - 15 years of work experience, $17 \%$ have 16 - 20 years of work experience, $19 \%$ have 21 - 30 years of work experience, $1 \%$ have 31 - 40 years of work experience, and $1 \%$ have 41 or more years of work experience. Accordingly, the more years of work experience, the less likely it is for teachers to include ICT skills development courses in their training programs, especially for teachers with more than 20 years of work experience. 
Table 2 - The respondents' distribution by country, gender, and educational background

Country ID - Numeric Code

\begin{tabular}{|c|c|c|}
\hline & Frequency & Share $(\%)$ \\
\hline France & 4435 & 56.7 \\
\hline Netherlands & 3388 & 43.3 \\
\hline Total & 7823 & 100.0 \\
\hline \multicolumn{3}{|l|}{ Gender $-\mathrm{T}$} \\
\hline Female & 5484 & 70.1 \\
\hline Male & 2339 & 29.9 \\
\hline Total & 7823 & 100.0 \\
\hline \multicolumn{3}{|c|}{ Highest level of formal education completed $-\mathrm{T}$} \\
\hline Below $<$ ISCED 2011 Level 3> & 8 & 0.1 \\
\hline$<$ ISCED 2011 Level 3> & 143 & 1.8 \\
\hline$<$ ISCED 2011 Level 4> & 98 & 1.3 \\
\hline$<$ ISCED 2011 Level 5> & 129 & 1.6 \\
\hline$<$ ISCED 2011 Level 6> & 3475 & 44.4 \\
\hline$<$ ISCED 2011 Level 7> & 3789 & 48.4 \\
\hline <ISCED 2011 Level 8> & 163 & 2.1 \\
\hline Total & 7805 & 99.8 \\
\hline Not Reached & 1 & 0.0 \\
\hline Omitted or invalid & 17 & 0.2 \\
\hline Total & 18 & 0.2 \\
\hline Total & 7823 & 100.0 \\
\hline
\end{tabular}

Source: Compiled by the authors based on OECD (2019)

\section{Results}

Fifty percent of higher education teachers claim the inclusion of blended learning teaching components in formal education, while $45.6 \%$ indicated the absence of such elements in training programs (Table 3 ); $48.4 \%$ of teachers claim the inclusion of elements of ICT use in further learning activities in educational training programs; $13.1 \%$ of teachers noted that categories of technology-related subjects (technology orientation including information technology, computer research, construction/geodesy, electronics, graphics and design, keyboarding skills, word processing, workshop technology/design technology) were included in their formal education; $65.7 \%$ noted the absence of such subjects in their formal education. At the same time, $12.3 \%$ of teachers taught these subjects to students, while $66.6 \%$ didn't teach these subjects. It may have influenced teachers' completion of professional development courses to acquire the ICT skills needed to teach students: $44.3 \%$ of teachers had taken professional development courses, while $44.4 \%$ had not taken such courses. 
Table 3 - Higher education teachers' assessment of the inclusion of teaching elements in a mixed ability setting in formal education; elements of ICT for teaching; inclusion of subjects teaching the use of technology in France and the Netherlands

\begin{tabular}{|l|c|c|c|c|}
\hline Questions & Yes & No & No answer & Total \\
\hline Elements in formal education teaching in a mixed ability setting & 50.0 & 45.6 & 4.3 & 100 \\
\hline Elements in formal education use of ICT for teaching & 48.4 & 47.4 & 4.3 & 100 \\
\hline Subject categories included in formal education and train technology & 13.1 & 65.7 & 21.2 & 100 \\
\hline Subjects taught in current school year technology & 12.3 & 66.6 & 21.2 & 100 \\
\hline Areas professional development ICT skills for teaching & 44.3 & 44.4 & 11.3 & 100 \\
\hline
\end{tabular}

Source: Compiled by the author based on OECD (2019)

A total of $30.3 \%$ of higher education teachers rated their level of readiness to use ICT in teaching as very low, $34.2 \%$ as low, $18.7 \%$ as good, and $3.0 \%$ as very good.

Table 4 shows the indicators of higher education teachers' readiness for teaching in mixed ability settings, Use of ICT for teaching in France, the Netherlands. 28.9\% of educators are practically not ready for blended learning, 36.6\% indicated a low level of readiness, $18.0 \%$ rated their level of preparedness as good, and 3.3\% indicated a high level.

Higher education teachers who had undergone professional development of ICT skills for teaching noted the most positive effects: it adapted to my personal development needs (89\%); it provided opportunities to practice/apply new thoughts and knowledge in our classroom (88\%); it built on my prior knowledge (85\%); it provided opportunities for active learning $(78 \%)$; it had a coherent structure $(73 \%)$; it provided opportunities for educational learning (72\%); it appropriately focused on the content needed to teach my subjects $(71 \%)$; it was based on innovation in my treatment (68\%) (Table 5).

Table 4 - Assessment of higher education teachers' readiness to teach in a mixed ability setting, Use of ICT for teaching in France and the Netherlands

\begin{tabular}{|l|c|c|}
\hline \multicolumn{2}{|l|}{ Frequency } & $\%$ \\
\hline Preparation for technological elements, teaching in a mixed ability setting \\
\hline Not at all & 2,262 & 28.9 \\
\hline Somewhat & 2,866 & 36.6 \\
\hline Well & 1,407 & 18.0 \\
\hline Very well & 261 & 3,3 \\
\hline Total & 6,796 & 86,9 \\
\hline
\end{tabular}

RPGE- Revista on line de Política e Gestão Educacional, Araraquara, v. 25, n. 3, p. 2241-2257, Sep./Dec. 2021. e-ISSN: 1519-9029 
No answer

1,027

13,1

Preparation for technological elements, use of ICT for teaching

\begin{tabular}{|l|c|c|}
\hline Not at all & 2,374 & 30,3 \\
\hline Somewhat & 2,677 & 34,2 \\
\hline Well & 1,459 & 18,7 \\
\hline Very well & 234 & 3,0 \\
\hline Total & 6744 & 86,2 \\
\hline No answer & 1,079 & 13,8 \\
\hline
\end{tabular}

Source: compiled by the author based on OECD (2019)

Table 5 - Type of impact of the professional development activity that had the greatest positive impact on teaching during the last 12 months in France and the Netherlands

\begin{tabular}{|l|c|c|c|c|}
\hline Type of impact & Yes & No & Yes & No \\
\hline a) It built on my prior knowledge. & 2,369 & 411 & $85 \%$ & $15 \%$ \\
\hline b) It adapted to my personal development needs. & 2,472 & 310 & $89 \%$ & $11 \%$ \\
\hline c) It had a coherent structure. & 2,030 & 742 & $73 \%$ & $27 \%$ \\
\hline d) It appropriately focused on content needed to teach my subjects. & 1,977 & 800 & $71 \%$ & $29 \%$ \\
\hline e) It provided opportunities for active learning. & 2,160 & 615 & $78 \%$ & $22 \%$ \\
\hline f) It provided opportunities for collaborative learning. & 2,001 & 775 & $72 \%$ & $28 \%$ \\
\hline $\begin{array}{l}\text { g) It provided opportunities to practice/apply new ideas and knowledge in my } \\
\text { own classroom. }\end{array}$ & 2,433 & 345 & $88 \%$ & $12 \%$ \\
\hline h) It provided follow-up activities. & 1,177 & 1592 & $43 \%$ & $57 \%$ \\
\hline i) It took place at my school. & 1,196 & 1583 & $43 \%$ & $57 \%$ \\
\hline j) It involved most colleagues from my school. & 1,016 & 1760 & $37 \%$ & $63 \%$ \\
\hline k) It took place over an extended period (e.g., several weeks). & 1,121 & 1655 & $40 \%$ & $60 \%$ \\
\hline l) It focused on innovation in my teaching & 1,889 & 887 & $68 \%$ & $32 \%$ \\
\hline
\end{tabular}

Source: compiled by the author based on OECD (2019)

Correlation analysis indicates a significant relationship (at a significance level of 1\%) between the components of formal education in the context of learning to work in a mixed environment, teachers' readiness to learn in a mixed environment, components of teachers' preparation to use teachers, and teachers' readiness to use ICT (Table 6).

Table 6 - Correlation analysis (Pearson correlation)

\begin{tabular}{|c|l|c|c|c|c|c|c|c|c|c|}
\hline \multicolumn{2}{|c|}{} & 1 & 2 & 3 & 4 & 5 & 6 & 7 & 8 \\
\hline & $\begin{array}{l}\text { Elements in } \\
\text { form. educ. }\end{array}$ & $\begin{array}{l}\text { Correlation } \\
\text { Teaching in a } \\
\text { mixed ability } \\
\text { setting }\end{array}$ & $\begin{array}{l}\text { Significance } \\
\text { (bilateral) }\end{array}$ & $0.626^{* *}$ & $0.231^{* *}$ & $-\begin{array}{c}- \\
0.176^{* *}\end{array}$ & $0.083^{* *}$ & $0.060^{* *}$ & -0.003 & -0.002 \\
\hline 2 & $\begin{array}{l}\text { Prep. for tch. } \\
\text { elements }\end{array}$ & Correlation & $\begin{array}{c}- \\
0.626^{* *}\end{array}$ & 1 & 0.000 & 0.000 & 0.000 & 0.000 & 0.808 & 0.869 \\
\hline
\end{tabular}




\begin{tabular}{|c|c|c|c|c|c|c|c|c|c|c|}
\hline & $\begin{array}{l}\text { Teaching in a } \\
\text { mixed ability } \\
\text { setting }\end{array}$ & $\begin{array}{l}\text { Significance } \\
\text { (bilateral) }\end{array}$ & 00.000 & & 0.000 & 0.000 & 0.000 & 0.599 & 0.155 & 0.069 \\
\hline \multirow[b]{2}{*}{3} & \multirow{2}{*}{$\begin{array}{l}\text { Elements in } \\
\text { form. educ. } \\
\text { Use of ICT } \\
\text { for teaching }\end{array}$} & Correlation & $0.231^{* *}$ & $\begin{array}{c}- \\
0.116^{* *}\end{array}$ & 1 & $\begin{array}{c}- \\
0.646^{* *}\end{array}$ & $0.156^{* *}$ & $0.044^{* *}$ & $0.058^{* *}$ & $0.139^{* *}$ \\
\hline & & $\begin{array}{l}\text { Significance } \\
\text { (bilateral) }\end{array}$ & 0.000 & 0.000 & & 00.000 & 0.000 & 0.001 & 0.000 & 0.000 \\
\hline \multirow{2}{*}{4} & \multirow{2}{*}{$\begin{array}{l}\text { Prep. for tch. } \\
\text { elements Use } \\
\text { of ICT for } \\
\text { teaching }\end{array}$} & Correlation & $\begin{array}{c}- \\
0.176^{* *}\end{array}$ & $0.285^{* *}$ & $\begin{array}{c}- \\
0.646^{* *} \\
\end{array}$ & 1 & $\begin{array}{c}- \\
0.157^{* *}\end{array}$ & $\begin{array}{c}- \\
0.043^{* *} \\
\end{array}$ & $\begin{array}{c}- \\
0.093^{* *} \\
\end{array}$ & $0.244^{* *}$ \\
\hline & & $\begin{array}{l}\text { Significance } \\
\text { (bilateral) }\end{array}$ & 0.000 & 0.000 & 00.000 & & 0.000 & 0.002 & 0.000 & 0.000 \\
\hline \multirow[b]{2}{*}{5} & \multirow{2}{*}{$\begin{array}{l}\text { Subject cat. } \\
\text { inc in form. } \\
\text { educ. and } \\
\text { train } \\
\text { Technology }\end{array}$} & Correlation & $0.083^{* *}$ & $\begin{array}{c}- \\
0.054^{* *}\end{array}$ & $0.156^{* *}$ & $\begin{array}{c}- \\
0.157^{* *}\end{array}$ & 1 & $0.444^{* *}$ & 0.022 & $0.060^{* *}$ \\
\hline & & $\begin{array}{l}\text { Significance } \\
\text { (bilateral) }\end{array}$ & 0.000 & 0.000 & 0.000 & 0.000 & & 0.000 & 0.109 & 0.000 \\
\hline \multirow[b]{2}{*}{6} & \multirow{2}{*}{$\begin{array}{l}\text { Subjects } \\
\text { taught in } \\
\text { current school } \\
\text { year } \\
\text { Technology }\end{array}$} & Correlation & $0.060^{* *}$ & -0.007 & $0.044^{* *}$ & $\begin{array}{c}- \\
0.043^{* *}\end{array}$ & $0.444^{* *}$ & 1 & -0.017 & 0.015 \\
\hline & & $\begin{array}{c}\text { Significance } \\
\text { (bilateral) }\end{array}$ & 0.000 & 0.599 & 0.001 & 0.002 & 0.000 & & 0.199 & 0.242 \\
\hline \multirow{2}{*}{7} & \multirow{2}{*}{$\begin{array}{lr}\text { Areas } & \text { prof. } \\
\text { dev. } & \text { ICT } \\
\text { skills } & \text { for } \\
\text { teaching } & \end{array}$} & Correlation & -0.003 & -0.018 & $0.058^{* *}$ & $\begin{array}{c}- \\
0.093^{* *}\end{array}$ & 0.022 & -0.017 & 1 & -0.010 \\
\hline & & $\begin{array}{l}\text { Significance } \\
\text { (bilateral) }\end{array}$ & 0.808 & 0.155 & 0.000 & 0.000 & 0.109 & 0.199 & & 0.387 \\
\hline \multirow{2}{*}{8} & \multirow{2}{*}{$\begin{array}{lr}\text { Prof. } & \text { dev } \\
\text { needs } & \text { ICT } \\
\text { skills } & \text { for } \\
\text { teaching } & \end{array}$} & Correlation & -0.002 & -0.022 & $0.139^{* *}$ & $-\overline{-}^{-244^{* *}}$ & $0.060^{* *}$ & 0.015 & -0.010 & 1 \\
\hline & & $\begin{array}{l}\text { Significance } \\
\text { (bilateral) }\end{array}$ & 0.869 & 0.069 & 0.000 & 0.000 & 0.000 & 0.242 & 0.387 & \\
\hline
\end{tabular}

*The correlation is significant at the 0.01 level (bilateral)

Source: Prepared by the authors

At the same time, a positive correlation was found between the components of formal education in the context of learning to work in a mixed environment and the components of teacher preparation for ICT use (0.231); teacher readiness for learning in a mixed environment and teacher readiness for ICT use (0.285); the components of teacher preparation for ICT use and the inclusion of technology education subjects in teacher formal education (0.156); the inclusion of technology education subjects in teacher formal education and current teaching. However, a negative relationship was found between the components of formal education in the context of blended learning and teachers' readiness for blended learning (-0.626); teachers' readiness for ICT use (-0.176); teachers' preparation components for ICT use and teachers' readiness for ICT use $(-0.646)$. 


\section{Discussion}

This research revealed an average level of inclusion of teacher training components for blended learning (50.5\%) and training components for ICT use in student learning (48.4\%). A significant level of teachers' professional development of ICT skills was also revealed (44\% take courses). As a consequence, an average level of unpreparedness of teachers for both blended learning (28.9\% are not ready, $36.6 \%$ are little prepared) and the use of ICT in practice (30.3\% are almost not ready, 34.25 are little prepared) was revealed. The study also allows us to state the fact of the connection between the components of teachers' preparation for a blended learning environment and the subsequent passage of professional courses for ICT skills development. It means that formal education does not guarantee the absence of the need for continuous professional development and the formation of a wide range of ICT skills. Teachers need continuous professional development and new ICT skills.

The study also found a synergy of positive effects of ICT skills professional development. Educators noted that the professional development courses were adjusted to their needs, which was also found in the findings of Porter et al. (2016). Consequently, respondents to Porter et al. (2016) noted the impact of individual professional development on skills by tailoring it to the specific needs addressed by the individual educator. In addition, according to the results, it is professional development that provides interaction among educators who share common challenges related to blended learning, technology, etc. This commonality ensures better communication and removes barriers, particularly in asking questions to address specific work tasks of the blended environment (HRASTINSKI, 2019). This study also identifies the possibility of borrowing new ideas, innovations, and practices in professional development, updating professional knowledge, using active collaborative learning, and the integrity of the professional development framework. Additional effects of educators' professional development, according to Porter et al. (2014), are individual help, support, collaborative learning, opportunity to learn from other educators' questions, understanding, availability of real-time responses, and instant feedback.

Among the main advantages of blended learning, particularly in contrast to fully online learning, are a higher level of impact on student success through face-to-face communication and more effective face-to-face interaction through body language, the ability to receive real-time feedback. Despite the higher level of flexibility of online learning, this form of teaching is less beneficial to both students and faculty (PORTER et al., 2016). 
The need for professional development of ICT skills identified in this study is primarily related to mastering new technologies needed in a blended learning environment. For example, the use of a learning management system is the best technological solution for blended learning teachers. Certain learning management systems use data dashboards to allow instructors to monitor student progress (PULHAM; GRAHAM, 2018). Many learning management systems have customizable content page options or software to create playlists for educators to use to make curriculum content and assessments available to students or to customize the curriculum as needed (BORUP et al., 2020; SPRING; GRAHAM; HADLOCK, 2016). Managing software is the second most cited technology skill for BL teachers (ARNESEN et al., 2019). Confidence in teaching software is key in a changing environment (ARNEY, 2014). Often third-party software packages, such as Khan Academy (https://www.khanacademy.org/), provide educators with instructional content. The understanding of how these software platforms work and integrate with students' curriculum is critical to provide a coherent integrated curriculum, as well as helping students to learn and master subjects (PULHAM; GRAHAM, 2018).

\section{Conclusion}

The study revealed an average level of inclusion of teacher training components for blended learning (50.5\%) and training components for ICT use in student learning (48.4\%). A significant level of teachers' professional development of ICT skills was also revealed (44\% take courses). As a consequence, an average level of unpreparedness of teachers for both blended learning (28.9\% are not ready, $36.6 \%$ are little prepared) and the use of ICT in practice (30.3\% are almost not ready, 34.25 are little prepared) was revealed.

The study also allows us to state the fact of the connection between the components of teachers' preparation for a blended learning environment and the subsequent passage of professional courses for ICT skills development. It means that formal education does not guarantee the absence of the need for continuous professional development and the formation of a wide range of ICT skills. Teachers need continuous professional development and new ICT skills. The paper also identified synergies of positive effects of ICT skills professional development (interaction of educators united by common problems related to blended learning, technology, etc.; borrowing new ideas, innovations, and practices during professional development; updating professional knowledge; using active collaborative 
learning; integrity of professional development structure). Teachers noted that it was the professional development courses that were adapted to their needs.

\section{REFERENCES}

ARNESEN, K. T. et al. Experiences with Personalized Learning in a Blended Teaching Course for Preservice Teachers. Journal of online learning research, Waynesville, v. 5, n. 3, p. 275-310, 2019. Available: https://www.learntechlib.org/primary/p/210637. Access: 5 Dec. 2021.

ARNEY, L. Go blended!: A handbook for blending technology in schools. Hoboken: John Wiley \& Sons, 2014.

BORUP, J. et al. Academic Communities of Engagement: an expansive lens for examining support structures in blended and online learning. Educational Technology Research and Development, Chestnut Hill, v. 68, n. 2, p. 807-832, 2020. DOI: https://doi.org/10.1007/s11423-020-09744-x

DZIUBAN, C. et al. Blended learning: the new normal and emerging technologies.

International Journal of Educational Technology in Higher Education, Barcelona, v. 15, n. 1, p. 1-16, 2018. DOI: https://doi.org/10.1186/s41239-017-0087-5

GRAHAM, C. R. Blended learning models. In: KHOSROW-POUR, M. Encyclopedia of Information Science and Technology. 2. ed. Pennsylvania: IGI Global, 2009. p. 375-382. DOI: https://doi.org/10.4018/978-1-60566-026-4.ch063

GRAHAM, C. R. Current research in blended learning. In: Handbook of distance education. England: Routledge, 2013a. p. 173-188.

GRAHAM, C. R. Emerging practice and research in blended learning. In: Handbook of distance education. England: Routledge, 2013b. p. 351-368.

GRAHAM, C. R. et al. K-12 Blended Teaching Readiness: Model and Instrument Development. Journal of Research on Technology in Education, Gainesville, v. 51, n. 3, p. 239-258, 2019. DOI: https://doi.org/10.1080/15391523.2019.1586601

HRASTINSKI, S. What do we mean by blended learning? TechTrends, Statesboro, v. 63, n. 5, p. 564-569, 2019. DOI: https://doi.org/10.1007/s11528-019-00375-5

LÓPEZ-PÉREZ, M. V.; PÉREZ-LÓPEZ, M. C.; RODRÍGUEZ-ARIZA, L. Blended learning in higher education: Students' perceptions and their relation to outcomes. Computers \& Education, Tempe, v. 56, n. 3, p. 818-826, 2011. DOI:

https://doi.org/10.1016/j.compedu.2010.10.023

MANWARING, K. C. et al. Investigating student engagement in blended learning settings using experience sampling and structural equation modeling. The Internet and Higher Education, Hong Kong, v. 35, p. 21-33, 2017. DOI: https://doi.org/10.1016/j.iheduc.2017.06.002 
MOSKAL, P.; DZIUBAN, C.; HARTMAN, J. Blended learning: A dangerous idea? The Internet and Higher Education, Hong Kong, v. 18, p. 15-23, 2013. DOI:

https://doi.org/10.1016/j.iheduc.2012.12.001

\section{ORGANISATION FOR ECONOMIC COOPERATION AND DEVELOPMENT. TALIS}

2018 Results (Volume I): Teachers and School Leaders as Lifelong Learners. Paris: OECD Publishing, 2019. DOI: https://doi.org/10.1787/1d0bc92a-en

PORTER, W. W. et al. Blended learning in higher education: Institutional adoption and implementation. Computers \& Education, Tempe, v. 75, p. 185-195, 2014. DOI:

https://doi.org/10.1016/j.compedu.2014.02.011

PORTER, W. W. et al. A qualitative analysis of institutional drivers and barriers to blended learning adoption in higher education. The internet and Higher education, Hong Kong, v. 28, p. 17-27, 2016. DOI: https://doi.org/10.1016/j.iheduc.2015.08.003

PULHAM, E.; GRAHAM, C. R. Comparing K-12 online and blended teaching competencies: a literature review. Distance Education, London, v. 39, n. 3, p. 411-432, 2018. DOI: https://doi.org/10.1080/01587919.2018.1476840

PULHAM, E.; GRAHAM, C.; SHORT, C. Generic vs. Modality-Specific Competencies for K-12 Online and Blended Teaching. Journal of Online Learning Research, Waynesville, v. 4, n. 1, p. 33-52, 2018. Available: https://files.eric.ed.gov/fulltext/EJ1174455.pdf. Access: 5 Dec. 2021.

SMITH, K.; HILL, J. Defining the nature of blended learning through its depiction in current research. Higher Education Research \& Development, Hobart, v. 38, n. 2, p. 383-397, 2019. DOI: https://doi.org/10.1080/07294360.2018.1517732

SPRING, K. J.; GRAHAM, C. R.; HADLOCK, C. A. The current landscape of international blended learning. International Journal of Technology Enhanced Learning, Geneva, v. 8, n. 1, p. 84-102, 2016. DOI: https://doi.org/10.1504/IJTEL.2016.075961

VAUGHAN, N. Perspectives on Blended Learning in Higher Education. International Journal on E-learning, Waynesville, v. 6, n. 1, p. 81-94, 2007. Available:

https://eric.ed.gov/?id=EJ747810. Access: 5 Dec. 2021. 


\section{How to refer to this paper}

CHERVONYI, P.; ALIEKSIEIEVA, S.; SENCHYLO-TATLILIOGLU, N.; CHASTNYK, O.; DIOMIDOVA, N. Peculiarities of the higher education development in a blended learning environment. Revista online de Política e Gestão Educacional, Araraquara, v. 25, n. 3, p. 2241-2257, $\quad$ Sep./Dec. 2021. e-ISSN: 1982-5587. DOI: https://doi.org/10.22633/rpge.v25i3.15959

Submitted: 07/09/2021

Required revisions: $10 / 10 / 2021$

Approved: $11 / 11 / 2021$

Published: 08/12/2021 